\title{
Reading the Story of Majnun Layla through Qassim Haddad's Poem
}

\author{
Dzia Fauziah, Maman Lesmana \\ Arabic Studies Program, Faculty of Humanities Universitas Indonesia
}

\begin{abstract}
Majnun Layla is a popular classic story in the Middle East. It is said that this story inspired Shakespeare to write the story of Romeo and Juliet in Europe. The story spread to several cultures in the world and was rewritten in poetry, romance, drama and film genres. This paper aims to examine the story from the genre of modern poetry written by Qassim Haddad, a Bahrain poet. This research uses library data, both print and electronic, as research corpus and reference. The method used in this paper is the qualitative method, which prioritises words rather than numbers and emphasises quality over quantity. The data is presented in the form of analytical descriptive, starting from the description of its structure, until the analysis of its contents. In the analysis, semiotic structuralism is also used, which emphasises the text and its intrinsic elements. From the results of this study, it is found that there are not many images of the MajnunLayla's love story revealed in the poem because of it is a monologue form and not a narrative, and there are many phrases that are less understandable because the poem is rich in figurative words and unclear connotations. This paper recommends the story to be inspired well, it should be written in the form of a diaphanous and easily digestible poem, rather than prismatic andcomplicated.It is expected to be written in the form of a free and prosaic poem, with simple typography and does not necessarily use too many enjambments.
\end{abstract}

Keywords: Majnun Layla, love, Arab, poetry, Qassim Haddad

\section{INTRODUCTION}

Researches on Majnun Layla have been conducted by researchers in many other parts of the world, both past and present, from various fields of science: literature, psychology, religion and other fields, as well as from various perspectives. This research will also discuss the story, the story of MajnunLayla written in a modern poetry genre written by Qassim Haddad, a poet from Bahrain. The purpose of this research is to see how far Qassim Haddad can describe the story in his poetry.

Before entering into the main discussion, it is better if we know in advance the general picture of the story. Smith mentioned that the story of Majnun Layla is a Bedouin Arabic story, its title means "crazy about Layla". This story tells about a young man named Qays, who falls in love with a beautiful girl named Layla. In some versions it is mentioned that Qays and Layla know each othersince childhood, but another versions of the story mention that Qays has always known Layla ever since he saw her beauty and fell in love instantly. (2007: 110)

Schielke added that there are some variations on MajnunLayla's story, but the main points are the sameregardingQays and Layla knows each othersince childhood and fall in love, but Qays cannot marry Layla, because Layla's father will marry him with another man. Layla goes with her husband to his village, until she suffers from an illness and passes away. Qaysis left alone and loses his mind. He lives in the middle of the desert surroundedby many animals and recites poems about his burning longing for Layla. (2015)

The poems of Majnun Layla, written in the genre of love poems, has been popular in the Middle East since medieval times, the same as for the stories of Romeo and Juliet in Europe. In the 12th century, the poem was rewritten by the Persian poet, Nizami, in the perspective of mystical soul of Islam. Then, in the 20th century, an Egyptian poet named Ahmad Shawqi, wrote the story in the form of a modern drama and his work has been followed by modern-day poets until now. (Schielke, 2015)

As one of the travel stories, from time to time, the story of Majnun Layla spread to several cultures in the world through the spread of Islam, such as Persia, Turkey, and Urdu, even to the West in the form of poetry, romance, drama and film. In medieval Persian literature there are two authors who wrote the romance version, Nizami (d. 1217) and Jami (1492). (Campo, 2009: 449).

There are some narrative poems that talk about the love story of Majnun Layla, in Arabic, Persian, Turkish, and other languages, and a large number of Arabic poemstalking about Qays alone, which describe his love for Layla and the sadness that befalls him. However, only a few of them talk about Layla alone. In any romance genre work, most of the story was aboutMajnun (the crazy Qays) lamenting his sorrow for his unrequited love and finally dying of his suffering. (Lewis, tt: 24) 
One of the poets who wrote about the story of MajnunLayla is Qassim Haddad, a poet from Bahrain. Bahrain is a small island nation in the Arabian Gulf, east of Saudi Arabia, which has undergone radical changes in the last fifty years and is moving from a traditional lifestyle to a modern lifestyle. (Haddad 2014: 1). In Bahrain, poetry has a very long history and poets have a much respected position. (Creative, 2004: 27)

No one can capture this drastic transformation and live as expressively as the Bahraini poet Qassim Haddad. (Haddad 2014: 1). He is the most innovative poet in the Gulf State and possibly in the Arab Country. At the beginning of his creation, he wrote poems on social and political themes with satire. (Marhamah, 2015: 8).

Qassim Haddad was born in Muharraq, one of the cities of Bahrain, in 1948. He lived in thisregion before the advent of modernization. Muharraq, the city which lies between the land and the sea, is the home to a community of people whose public relations are very close. In Muharraq, the door of people's houses is always open to anyone, including Haddad's house, which is home to social, religious and economic activities. His family name is Haddad, literally "Black Iron Clone", because his father worked as a blacksmith although having previously worked as a pearl seeker, a special and dangerous job for the people of Bahrain back then before they discovered the oil. As a child, Qassim helped his father work by forging and making iron and other metals.

In terms of education, prior to entering formal schooling, he studied at al-Kuttab, a religious preschool that gave him the science of how to read and memorize the Qur'an. Afterwards, he went on to formal school, exploring the contemporary world. However, it seems that Haddad did not feel comfortable studying in a formal school, because he was not free, so he decided to quit from high school and work at the national library as a staff from 1968-1975.

This position allowed him to read more materialsto explore. (Haddad 2014: 2). Since childhood, Haddad lived in a traditional Gulf Arab society and grew up self-taught. Due to his position as a librarian and his ideology, he succeeded in assimilating a contemporary outlook, adapting his traditional vision into the modern style, without sacrificing his local setting or wiping out the past heritage (Haddad 2014: 1).

In addition to being a political activist, he also devoted himself as a cultural activist, by opening new tools for art and culture. In 1969, he participated in the founding of the Bahrain Writers Association and played an important role in it. In 1970, he founded atheater in Bahrain. In 1980, he began to engage in journalism by writing a column in a weeklyjurnal. In addition, he also became an editor the journal called Kalimat in 1987 and a poetry site called Jihat al-Syi'r in 1990. (Haddad 2014: 2).

In 2001, Haddad received the prestigious Owais Foundation award for his achievements. He has published more than a dozen poetry collections, critical prose works, interviews and scientific papers. It can be assumed that he is the best poet in Arab Gulf and one of the best poets in the Arab world. He has attended poetry conferences and festivals in the Arab world, Europe and the USA. In his poetry he generally uses speculative and elusive symbols.His language is ambiguous and more personal, passing from traditional roots to a global horizon, so it is not surprising that in his work there is a mixture of classical themes with modern perspectives, a mixture of local motives with world literature, and a new interpretation of the legends of the past. (Haddad 2014: 5).

Aside of being known as a poet, Qassim Haddad is also known as a revolutionary. He wrote many poems on political themes, especially about freedom and progress. His first collection was published in 1971. To this date, he has published more than 16 books which spread across Beirut, London, Morocco, Kuwait and Bahrain. One of his work is MajnunLayla, which contains a mixture of poetry and paintings. Some of his booklets are equipped with photographs made by Saleh al-Azzaz, a Saudi photographer. (Paine, 2011: 2). Haddad is one of the poets included in the free poetry movement. His poetry speaks volumes about freedom, progress, love and revolution. Many of his poems are translated in English. (Torstrick, 2009: 44)

Such is the general description of the story of MajnunLayla and the poet Qassim Haddad that becomes the topic in this study.

\section{THEORETICAL BACKGROUND}

The poems about the love story of Majnun Layla by Qassim Haddad which is discussed in this article is about Qays and and about Layla. Qays and Layla are the main characters in the love story of LaylaMajnun, meaning "crazy about Layla". To start the discussion, it is important to understand the typography of the poems. Typography is the way of writing a poem to display certain structures that can be visually observed. The purpose of typographic functions are to show the visual artistic aspect, to create a certain sense of meaning and atmosphere, and to clarify the existence of a unit of meaning that the poet wishes to express (Aminuddin 1987: 146).

In the discussion of this aspect of the structure, we will discuss the stanza, the lines and the enjambments using several theories. According to Atmazaki, in Arabic poetry writing, the stanza does not have to be written to the right of the paper, but depends on the poet's wish. (Atmazaki, 1990:64). In poetry, the stanza has several roles, forming a unique typography or poetic form, forming a unity of meaning different from that of 
the other row group of meanings, and emphasizing an idea that shows the differences of each stanza. In addition, the stanza also serves to share a text in short "chapters". (Luxemburg, 1989:196). Meanwhile, the definition of a line is to contain, tounify, and tobear idea that is started to be written and expressed in words (Aminuddin, 1987:145), meanwhile an enjambment is the line break arrangement of words of a certain line transferred into the next line. This arrangement of enjambment is done to emphasise the poet's intent in poetry writing, to depitc the effect ofthe beauty of the shape and to build a certain atmosphere, or to build poetic images. (Tirtawirya, 1983: 35)

Meanwhile, in the discussion of the content, this article uses the theory of Ilmu al-Balagah(Arabic Rethorics), namely 'Ilmual-Ma'āni, 'Ilmu al-Bayān, and 'Ilmu al-Bad̄̇.'Ilmu al-Ma'āniis the study of how to deliver statements according to circumstances. This field discusses the origins of a statement for a particular purpose and its application as required. (Shaykh, 1989: 17). 'Ilmu al-Bayānis the study that describes phrases that are beautiful, balig (delivered well to the reader because it is suitable to the condition and situation of the reader) and impressive, as well as describes the meaningsin the clearest picture and in the closest way. Meanwhile, 'Ilmu al-Badī' is the study of how to beautify a word or a phrase (Lesmana, 2010: 143).

\section{DISCUSSION}

The first poem to be discussed in this article is the عن قيس (about Qays) poem:

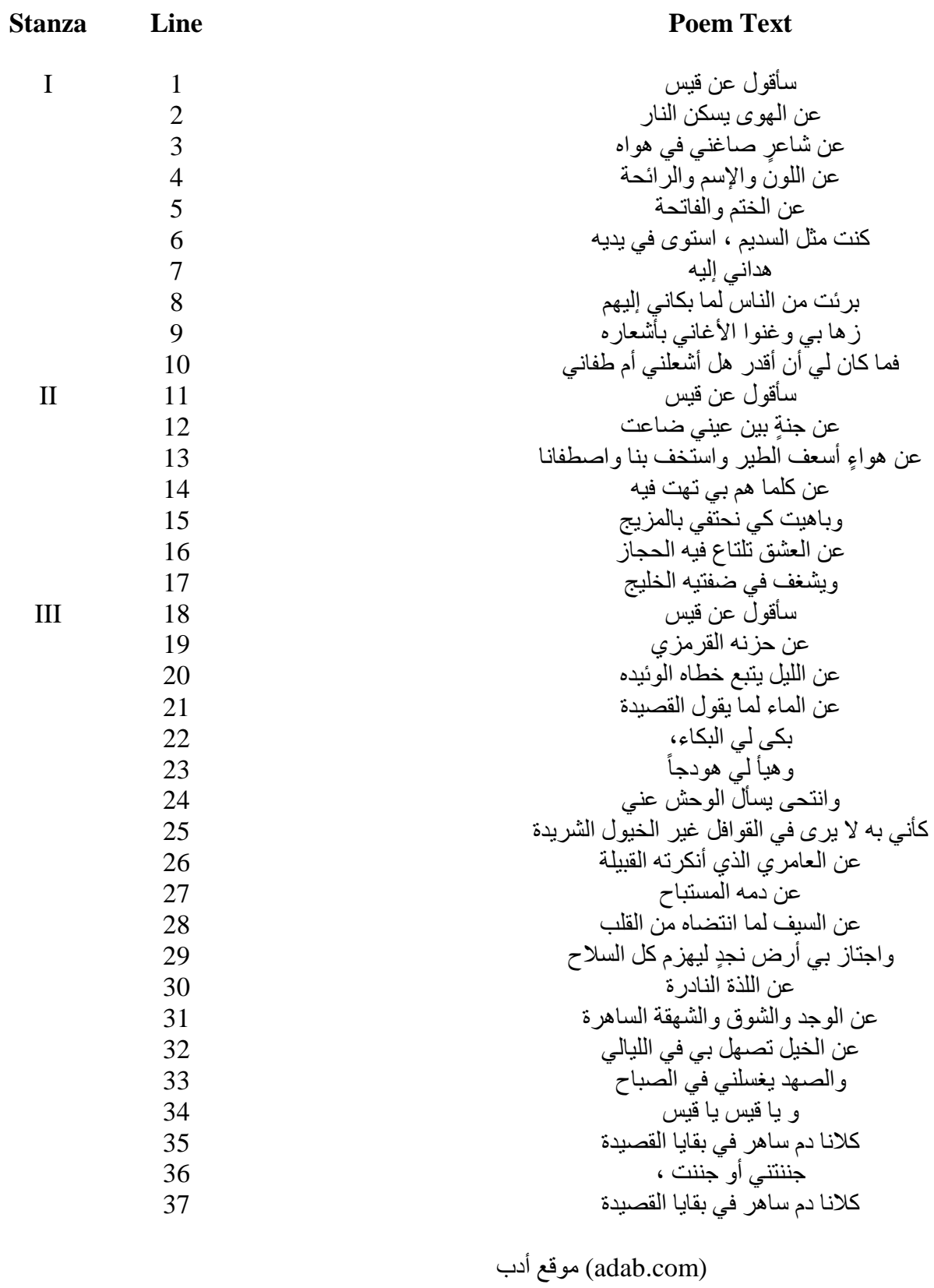


The poem is divided into 3 stanzas, each of which is marked with a sentence $I$ will tell about. The first stanza consists of 10 lines, stanza 2 consists of 7 lines and stanza 3 consists of 20 lines. The poem above does not start from the left edge nor end with a full stop. The use of punctuations in Arabic sentences is indeed not the same as the use of punctuations in Latin which always ends with a full stop and begins with a capital letter. This is due to the difference in script.

Haddad begins his poem in the first line of stanza I with the expression: /sa`aqulu 'an qays/. This line is a verbal sentence at present tense, indicated byIwill talk about Qays. In this line, it is mentioned that the subject in this line is $/ a /(I)$. Then who is actually $I$ in the lyrics of this line? Who is telling the story? To answer the questions above, the subject "I" in line 3, which means about a poet who makes love poems for me, is worth noting. In this line, there is a pronoun of the object /-ni/ (-me) in the sentence /saganifihawahu/ (make love poems for me). If it is associated with the subject "I" in line 1: I will talk about Qays, it can be assumed that the subject $\mathbf{I}$ in this line is Layla, because the subject of sairun (a poet) in this line is Qays.

Next, followed by line 2, about the love that lives in fire also begins with the word /'an/. By the use of this repetition, it can be assumed that the content after this particle is still related to the contents of the previous line. Thus, the intent of this line is that Layla will talk about Qays's love that is really profound. In this line Haddad uses some aspects of 'Ilmu Bayan. The first is the aspect ofistiaratmakniyat, as in the expression of alhawayaskunu (living love). In this text, "love" is likened to "man", it can live. The second is the aspect ofmajazmursalmusabbabiyyat. What is meant here is a burning love, but the word fire (an-nar) is used, because it is the fire that causes theburning.

The same thing goes forline 3 which begins with the /-an/ particle:about a poet who makes me a topic in his love poem, which undoubtedly refers toQays. Line 4 also begins with / an/ particle: about the colour, the name, and thescent. However, unlike previous lines, this line is not clear. There is no indication that these three words are connotative or figurative words. Referring to the previous line, it can be assumed that the meaning of the word /al-lawni/(colour), al- ismi (name) andar-ra ihat (scent) is the colour, the name and thescent of Layla. It is the continuation of line 3 which made Layla the topic in his poetry.

Likewise,line 5 begins with the particle / 'an /: In line 5, Layla wants to tell about the beginning (al-fatihat) and the end (al-khatam) of their love story. In general, the earliest things always take precedence over the end, but in this line, Haddad deliberately prioritises the word /al-khatam/ (end) than /al-fatihat/ (early), perhaps this is to show that the core of the story lies at its end.

After talking about Qays in line 1-5, then Layla talks about herself in line 6, which means I'm like a cloud over his hands. This means Layla says that she is like a cloud that is in both hands of Qays. In this line, Haddad uses tashbeeh. Layla is likened to a cloud, because it is not fixed at the moment, can be swayed by the wind.

The story then proceeds to line 7, which meanshe directed me to him. The point is that Qays directed the cloud to himself. Here, Haddad uses the aspect of 'makniyatisti'yat, that is, describing clouds having the ability to do something what humans can do.

Next, in line 8. Layla says that I was blamed by people, because Qays cried for himself in front of these people. In this line, Haddad uses the 'ilmu al-ma'ani,in the aspect offa'idat al-khabar that is to only provide information, without connotative or figurative meanings of it. What did Qays cry for? That is the departure of Layla, addressed in line 9. The word /zihabi/ (my departure) on (my departure and they sing their poems as songs) is actually a continuation from the previous line, /buri tu min an-nas five bakani ilayhizihabi/, however the line is truncated using an enjambment to the next line. The purpose of using this enjambment here seems to emphasise the word /zihabi/ (my departure), in order to appeal to reader's attention.

The meaning of the last line of stanza 1 is I cannot predict whether Qays's cryliven me up or only to extinguish me. The point is whether Qays's cry is to make her feelmore guilty or not. In this line Haddad uses the rhetorical aspects of $a l$-badi', Tibaq 'ijabi, which is the use of contradictory expressions in one statement, indicated by the words/'asala/ (ignite) andtafa (extinguish).

In addition to stanza 1, line 11 of stanza 2 also begins with the repeated words /sa 'aqulu 'an qays/. This line is the same as line 1 of the 1st stanza, which means(I will talk about Qays). In this line, Haddad uses the rhetorical aspect of 'ilmubayan, isti'arattasrihiyat, which only provides information that Layla will talk about Qays. Then, this is followed by the line 12 stanzas 2. In this line, Layla will tell about the loss of a paradise between her eyes. Using al-bayan, and isti'arattasrihiyat,Qays is likened to paradise. Likewise, the phrase Ibayna 'aynida'at/ (between his eyes), belongs to 'ilmubayan, in the aspect ofkinayat 'an nisbat. It means something that is already in sight.

In line 13, Layla will tell about a plume of air that followed a bird, some of us mocked it and some said good things about it. In this line Haddad uses the rhetorical aspect of'ilmubayan, 'isti'arattashrihiyat, as he likens Qays as the air and Layla as a bird. Thus, the expression air that followed the bird is the parable for Qays following Layla. If it refers to this story, semiotically, it can be interpreted, why Haddad prefers the word 
/istakhafa/ (mocking) rather than the word /istafanal (saying good things) to the line, this is because Haddad wants to emphasise that the number of people who mockedare more than the ones who said good things about the matter.

Next, in line 14, Layla will tell about whenever he is nervous about me, I'm in him. That is, every time Qays gets nervous on Layla, Layla comes to feel it. In this line Haddad does not use figurative or connotative phrases, he uses only the rhetorical aspect of ilmu al-ma'ani, fa 'idat al-khabar, which purpose is simply to provide information. This line isfollowed by line 15, which means and I do my best to keep us together. This line is a continuation of the line above, as it is indicated by a connection particle / wa/. In Arabicrhetoric, such cases can be incorporated into 'ilmu al-ma'ani, in the aspect ofal-wasl which is used to combine the same two statements in the aspect of information delivery.

After that, Laila continues her story in the 16th line, which means about a passionate love in which there is a divider. In this line, Haddad uses the rhetorical aspect of 'ilmu al-ma'ani, with the aim of tahassur (expressing sorrow), that Layla will tell about her passionate love with Qays, but there is one thing that prevents them from the love.

Proceeding with line 17: and love that burns on both sides, Haddad wrote that Layla will tell about their love that burns only from both sidesyet cannot unite, because it is blocked by that boundary. As mentioned in the previous two lines, this line is preceded by the / wa/ particle indicating that this line is a continuation of the previous line, using 'ilmu al-ma'ani, in the aspect ofal-waslto combine two statements with the same type, in this case isat-tahassur (expression of sadness).

Stanza 3 line 19 also begins with the words /sa'aqulu 'an Qays/ (I will talk about Qays), serving as a marker of the beginning of a stanza. This is followed by line 20: about his scarlet sadness. The pronoun of /-hi/ (his) in /an huznihi/ (sadness) refers to Qays. This means that Layla will tell about the deep sadness Qays suffers from. The word /al-qarmazi/ is actually used for colour, which is dark red, crimson or scarlet, but it is used in this lineas the word "sadness", so it means "deep sadness". In Arabic rhetoric this style of language is called isti aratmakniyat.

In line 21, Layla will tell about the night which followedhisunstablesteps. In this line, Haddad uses 'ilmubayan, in the aspect of 'isti'aratmakniyat. In this text, /al-layl-/ (night) is described as though it is a human whocan follow Qays steps. The pronoun /hu/ (it is) in the phrase/khatahu/(step) refers to Qays.

In line 22, Layla continues the story, about the tears mentioned by the poem. This line is,in fact, unfinished. The completesentence is supplemented by the phrase in line 23, the person who cries for me.Using an enjambment, Haddad makes this line more of a concern over the previous one. So, if the phrase/'an al-ma'i five yaqulu al-qasidat/ is combined with /baka li al-Buka\%, then the overall meaning that Layla wishes to convey is I will talk about the tears of the one who cries for me which is mentioned in the poem. The word /albuka / (crying person) refers to Qays. This is supported by the word /al-qasidat/ (poetry), which is the work of Qays as a poet.

The line above is then continued withline 24 . This line begins with the $/ w a /$ particle. This indicates that this line is still a continuation of the previous line. The subject of /-a/in that line is Layla. This means Layla will tell that/wahayya'a li haudajan/ (He provides me a litter). The point is the story that Qays has provided a stretcher for him. As it is known that in the life of the desert at that time, a stretcher was a very important item. Thus, the use of the word /haudajan/(litter, stretcher), is not just a stretcher interpreted literally, but a symbol of a very precious propertywhich not everyone can have it.

Line 25 also begins with the conjunction particle/wa/ which indicates that this line is still continuation of the previous line, and runs next to me accompanying me. Then, this is followed by line 26, which means as if I and he are only abandoned horses that do not fit in the caravan. In this line Haddad uses the rhetorical aspect of 'ilmual-bayan, tashbih(parabolic) using/ka 'anna/ (as if)particle, such as /ka anibihi/, (as if I and he), where "I" and "he" refer toLayla and Qays. Both are then likened to /al-khuyul as-saridah/(abandoned horses). The reason for this parables is because they both feel they have been abandoned by families who do not agree with their relationship.

In addition to using 'ilmu al-bayan, Haddad also uses the rhetorical aspect of'ilmu al-ma'ani,al-qasr, in order to emphasise the line. The pattern is as follows: /la .... gayr ..../, (no .... except ....). This is found in the line/la yara fi qawafilgayr al-khuyul as-saridah/, which means: there isnot anything visible in the caravan except abandoned horses.

In line 27, Layla will talk about the people of Bani Amir who are blamed by his tribe. What is meant by /al'amiri/ (Bani Amir) is Qays, as Ganjavi (2012: 9) mentions that at one time, in Arabia, there was a Bedouin Ruler named Syed Omri who lived and ruled over the Bani Amir. Qayswas the beloved child of the ruler. This line is followed by line 28, which means about his forbidden blood. The pronoun /hi/ (his) in word /dammihi/ (his blood) refers to Qays's, this shows that it is Qays'sblood. In this line, Haddad uses the rhetorical aspect of 'ilmu al-bayan, kinayat 'an an-nisbat, which means that the presence of Qays is not expected anymore. 
In line 29, Layla will tell about a sword pulled from the heart. The meaning of the sword here is Qays. Thus, the separation of Layla with Qays, is as painful as the pulling of a swordfrom the heart. This form of rhetoric is also called 'ilmu al-bayan, specifically the aspect of al-kinayat'an misbat. Next, this is followed by line 30, which means and together with me, we go through the land of Nejd to defeat all weapons. The pronoun $/-i /(I)$ in $/ b i /$ refers to Layla. This means that the suffering of Qays and Layla is alreadyfamiliar news among the people of the land of Nejd, even defeating all the news that is there.

The hardshipsinattaininghappiness then will be told by Layla on line 31, about the rare pleasure. In this line Haddad uses the rhetorical aspect of 'ilmu al-bayan, al-majaz al-'aqli, specifically using 'isnad almasdariyattype of the aspect, where he uses infinitive words of rare pleasure. The real meaning of this line is not literally about his rare pleasure, but it describes thathe is the sort of person who seldom tastes the feeling of happiness. However, this is answered by Layla in line 32, where she will tell about the passions of love, longing and moans that never die. That means, although they both rarely attainhappiness, but their passions of love, longing and moans never die.

The next is line 33. In this line, Layla will tell about the horse that neighs to me at night. In this line, Haddad uses the rhetorical aspect of 'ilmu al-bayan, isti'arattasrihiyat, which likens Qays with /al-khayl/ (horse), because he is assumed tobe strong and able to walk around like a horse. Meanwhile, /tashalu bi/ (neighs to $m e$ ), means that it comes to Layla every night.

Continued with line 34 , this line begins with the $/ w a /$ particle indicating that this sentence is still a continuation of the previous line. The meaning is and the flame that illuminates me in the morning. The pronoun of the object /ni/ (me) in the word /yugsiluni/ (the flame that illuminates me) points to Layla. In this line, Haddad also uses the rhetorical aspect of 'ilmu al-bayan, 'isti'arattasrihiyat, which likens Qays with as-sahd (flame), because he is considered to be illuminating.

Haddad ends his poem with the last four lines beginning with line 34. Beginning with the particle /annida/ (exclamation): /wa ya Qays ya Qays/ (O Qays, O Qays). Discussion about /an-nida/ is included in 'ilmu al-Ma'ani. This indicates that the person being called is considered close to the heart. Next,line 35 , this literally can be translated asboth of us are a blood clot that are always awake at the end of poetry. However, the meaning of this line is that at the end of this story (baqaya al-qasidat), Qays and Layla are not actually dead (dammunsahirun), but it is only their bodies that die.

Next, line 36 is"You love me or I love you". The presence of /aw/ (or) particle in this line indicates an option. This style of language belongs to ilmu al-badi', specifically the aspect of muqabalah, which is the use of two expressions with inverted meanings in a statement. Then, who is the one that actually loves another? This question is responded in line 37, by the word /kilana/ (both of us)to answer to the question above. Therefore, there is no other choice. They will both love each other continuously (dammunsahirun) until the end of their life (fi baqaya al-qasidat).

Thus Haddad ended Layla's story of Qays in his poetry.

The second poem to be analysed in this article is the following poem:

\begin{tabular}{|c|c|c|}
\hline Stanza & Line & Poem Text \\
\hline \multirow[t]{11}{*}{ I } & 1 & سأقول عن ليلى \\
\hline & 2 & عن العسل الذي يرتاح في غنج على الزند \\
\hline & 3 & عن" الرمانة الكسلى \\
\hline & 4 & عن الفتوى التي سرت لي التشبيه بالقند \\
\hline & 5 & عن البدوية الَّعينين و النّارين و الخد \\
\hline & 6 & ل لها عندي \\
\hline & 7 & مغامرة تؤجج شهوة الشعر اء لو غنو ا \\
\hline & 8 & صبا نجدٍ منى قد هضت من نجد \\
\hline & 9 & عن النوم الثفيف يشي بنا \\
\hline & 10 & عن وجدنا ، عنهاً \\
\hline & 11 & لئلا تعرف الصحر اء غير العود و الرند \\
\hline \multirow[t]{6}{*}{ II } & 12 & سأقول عن ليلى \\
\hline & 13 & عن القتلى \\
\hline & 14 & وعن دمنا الذي هدروا \\
\hline & 15 & عن الوحش الُصديق \\
\hline & 16 & وفتنة العشاق \\
\hline & 17 & و الليل الذي يسعى له السهر \\
\hline \multirow[t]{2}{*}{ III } & 18 & عن الطفلين يلتقيان في خفرٍ \\
\hline & 19 & ولما يزهر التفاح يختلجان بالميزان \\
\hline
\end{tabular}




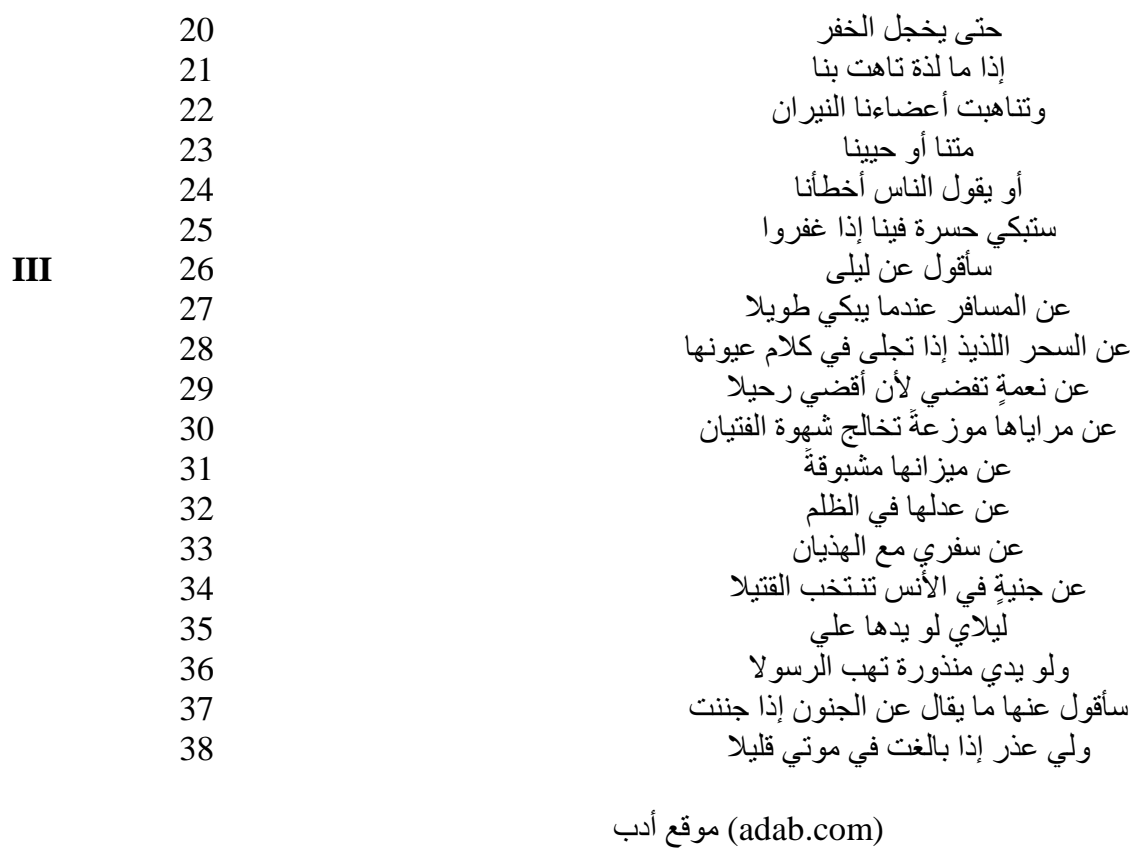

The poem is divided into three stanzas. Stanza 1 consists of 11 lines (1-11). Stanza 1 Line 1 begins with the words /sa'aqulu 'an layla/ (I will talkabout Layla). The same as in the discussion of poetry /'an Qays/, we will discuss this poem starting by addressingthe identity of "I"in this poem. The subject pronoun in the line/sa'qulu 'an layla/ (I willtalk about Laila), seems to refer to Qays. Therefore, it is Qays who will talk about Layla. This is supported by line 4 which means about women likened to me as sweets. The meaning of the pronoun of the object /-iy/ (me)in the phrase /-liy / to me) is Qays and line 6, which means "what hersis mine." The pronoun /-ha/ (her) is female, found in the phrase/laha/ (hers)which is addressed to Layla, and the pronoun /-iy/ (mine)in / 'indiy/ refers to Qays.

Next we can start discussingthe lines of the poem one by one, starting with line 2, which means about the honey that likes to play eyes with fire. In this line, Haddad used the rhetorical aspect of 'ilmu al-bayan, namely 'isti'arahtasrihiyat. In this context, Qays likens Layla to /al-asal/ (honey), because of her beauty. Haddad likens Qays to fire, because his love was so burning like fire. In addition, Haddad also uses therhetorical aspect of 'ilmu al-bayan, namely kinayat 'annisbat, that is to say the play of the eyesin replace tothe expression of 'getting closer to each other'.

Next is line 3. In this line, Layla is compared to /'an ar-ramanat al-kusla/, (lazy pomegranate). On one hand, Layla is likened to a pomegranate, because of its beauty. In Arabicrhetoric, this kind of figurative expression is called isti'arattashrihiyat, which belongs to 'ilmu al-bayan, but on the other hand Layla is said to be /al-kusla/ (lazy). Probably the word lazy here is neither active nor static. This is due to the fact that in the relationship between Qays and Layla, Layla is indeed more passive, because her activity is limitedand she is not allowed to be outdoors in order toseeQays, while Qays searches for Layla everywhere to seeher.

In line 4 Qays will tell about a woman likened to me assweets. The pronoun /-i/ ( me) in /-li / (to me) is Qays. What he means by a woman here is Layla. So, Qays will tell about Layla likened assweetsto him. In this line, Haddad usesat-tashbih (parabolic) language style by likening Layla to sweets.

In line 5, Qayswill talkabout the Bedouin woman whose eyes and cheeks are shining. The Bedouin womanmentioned in this line is Layla. This style of language is also called kinayat 'an al-mawsuf, which is included in the rethorical aspects of 'ilmu al-bayan. Direct information that says that Layla is a Bedouin woman has not been found, but there are indications that are headed to this conclusion.

This sentence is unfinished, because it is enclosed in the 6th line below, which means that what hers is mine. Therefore, as a whole, this line and the previous linecombine to the expressionthe Bedouin woman whose both eyes and radiant cheeks are mine. In this line Haddad uses the rhetorical aspect of 'ilmu al-badi', specifically uses tibaq `ijabifrommuhassinatma'nawiaspect, which mean what hers is mine.

Line 7 is an explanation of the previous two lines, which means an adventure that burns the lust of poets if they sing. In this line, Haddad uses `makniyatisti'yat, that is to personify adventures that can burn like fire. This line is actually unfinished, because there is a line break of enjambment. The continuation lies in line 8 , which means when the East wind is blowing from Nejd. So the complete sentence, if combined with the previous line, is an adventure that burns the lust of poets as they sing about when the East wind is blowing from Nejd. In this line, Haddad uses the rhetorical aspect of 'ilmu al-bayan, in the aspect ofkalam al-insha, in the aspect 
of 'istifham (question). The question particle used here is /mata/(when), but the intention is not to ask, rather it is to hope, becausethe people are expecting the arrival of the East wind.

Furthermore, in line 9, Qays will tell about the real dreams that talk about us. In this line Haddad used the rhetorical aspect of 'ilmu al-bayan, istiaratmakniyat, that is personifying dreams as people who can tell stories.

Likewise, Qays will also talkaboutour passion in love, about her, as it is written in line 10, where the word pronoun /na/ (us)in /wajadina/ (our passion in love)refers to Qays and Layla, while the pronoun /ha/ in l'anha/ (about her) is Layla. This means thatQays will tell about his and Layla's passion of love and about Layla. In this line Haddad does not use connotative or figurative words, he uses only 'ilmu al-ma'ani, in the aspect ofkalam al-khabar, whose purpose is only to inform (fa'idat al-khabar).

This line is also unfinished, so we proceed with line 11 afterwards to complete the sentence:that which is seen as a desert without wood and matches. If combined with the previous line, the meaning of this complete expression isabout Layla being likened to a desert without wood and matches. In this line, Haddad uses the rhetorical aspect of 'ilmu al-bayan, tashbih (parable), as Layla is likened toa desert and Qays is likened to wood and matches. Therefore, a desert without wood and matches is likeLayla without Qays.

The second stanza consists of 14 lines (line 12-25). The $12^{\text {th }}$ line, the first line of this stanza, begins by repeatingline 1 of stanza 1, which means I will talk about Layla. As already mentioned in line 1 of stanza 1 that the subject /a/ (I) in /sa'aqulu/ (I will talk) is Qays, it is Qays who will tell about the story. Just as at the beginning of each stanza, Haddad uses the rhetorical aspect of 'ilmu al-ma'ani, kalam al-khabar, whose purpose is fa'idat al-khabar, relaying information that Qays will talk about Layla.

Next we proceed with line 13, which means about the dead. What is meant by the dead here is Layla, since the adjective used is the adjective form for women. So the complete phrase is /layla al-qutla/, which means Layla is dead.

In line 14, Qays will talkabout our blood that they are fussing about. The meaning of the word /dammina/ (our blood) here is of course not the blood in the true sense, but blood in an unreal sense which may be interpreted as self.In Arabic rhetoric, this is called al-majaz al-mursal, Iyat(pars prototo)which talks about a technique of mentioning a part of things but actually it is referred to as a whole, in this case only'blood' is mentioned yet it is meant to be the person as a whole. Next we proceed to line 15. In this line, Qays will tell / an al-wahas as-sadiq/ (about the solitude that must be accepted). This is about the solitude of Qays. In this line, Haddad uses the rhetorical aspect of 'ilmu al-ma'ani,kalamkhabar, which denotes the meaning of tahassur (expressing sorrow).

This line is then followed by line 16, which means and the madness of the lover. The conjunction particle $/ w a /(a n d)$ in this line indicates that this line is still a continuation of the previous line, by usinga line break of enjambment. What is meant /al-'ussaq/ here is none other than Qays itself. So, if combined with the previous line, this linemeans that Qays wants to talk about himself who lives alone and becomes mad.

Next we continue with line 17. This line also begins with the conjunction particle / wa/ which indicates that this line is still a continuation of the previous line, meaning and the night that strives to not to sleep for him. What is meant by the pronoun /hu/ (him) in word /lahu/ for him) refers to Qays. So, the point of this expression is thatdue toQays's circumstances, even the night stays awake to accompany Qays. In this line Haddad used the rhetorical aspect of 'ilmu al-bayan, 'isti'aratmakniyat, to personify a night like a human who can stay awake.

Next, the story that will be told by Qays is about the meeting of two children who are always supervised. The two children here refer toQays and Layla. In line 18, Haddad uses al-ilmu al-ma'ani, usingistirhamtypeof the kalam al-khabaraspect, which is using a statement in order toto ask for mercy.

The $18^{\text {th }}$ line is then followed by the $19^{\text {th }}$ line, which means: and when the apple develops, they both are going beyond the ordinary. This line begins with the / $w a /$ (and)particle, indicating that this phrase is still related to the phrase above it, but there is a line break of enjambment added, because Haddad wants to emphasise the contents of each line. In Arabicrhetoric, the use of such particle is an obligation, since it combines two statements of the same formof kalam al-khabar. This form is included in the subject of ilmu alma'anicalled al-wasl. In addition, in this line, Haddad also uses the rhetorical aspect of ilmu al-bayan, kinayat 'an an-nisbat. The word /at-tufah/ (apple) in the clause /five yazhara at-tuffahu/(when the apple develops) is a parable for the word "when love grows."

Next, we proceed with line 20, which means until the guardment becomes embarrassed on its own. This line is also a continuation of the previous line, but there is a line break of enjambment added, with the intention that this linemay appeal to readers' attention. In this line Haddad used the rhetorical aspect of 'ilmu albayan, makniyat 'isti'arah, in order to personify /al-khafar/ (guardment) like man who has acharacteristic of being embarrassed.

Next is line 21, which means when none of the pleasure is lost from us. This line is also a continuation from the previous line. Therefore, the overall meaning of these two lines combined is that even the guardment becomes embarrassed, when none of the pleasure is lost from us. That means, although under surveillance, Qays 
and Layla are always happy. In this line, Haddad uses 'ilmu al-ma'ani, in the aspectof kalam al-khabar, whose purpose is to showal-fakhr (pride).

The $21^{\text {st }}$ line is then followed by the $22^{\text {nd }}$ line, which means and (the extent of how)our burning limbs are holding onto each other. That means, in addition to always being happy, their limbs are always holding onto each other inseparably although they are always guarded. This line begins with $/ \mathrm{wa} /$ particle which indicates that this phrase is still a continuation of the previous phrases. As already mentioned, in Arabic rhetoric this is called al-wasl, as it combines two statements with the same purpose, which is to give information. In addition to using al-wasl, Haddad also uses the rhetorical aspect of 'ilmu al-bayan, in the aspect of majazmursal, with'alaqatjuz'iyat, which is mentioning a part of an idea, in order to convey the whole idea entirely. In this line it is said that / 'a'dauna/(our limbs)are burning, whereas what is actually meant is /jismuna/(our whole body).

Then, we proceed to line 23 , which means we died or we lived. That means that it is either in the state of dead or alive. It can be seen from the pronoun /-na/ (we) in /mitna 'aw hayayna/. In this line Haddad uses the rhetorical aspect of 'ilmu al-badi', namely tibaq, which is the useof contradictory phrases in one statement: /mitna 'aw hayayna/ (we died or we lived).

Next, we proceed toline 24, which means or people tell about our mistakes. This line starts with the conjunction particle/ $a w /(o r)$ which indicates that this sentence is still part of the previous sentence, but there is a line break of enjambment added. The aim of this addition of enjambment is to emphasise on this line.

Looking at its meaning, this statement isincomplete. The truncated part is in the $25^{\text {th }}$ line, which means our sadness will continue to weep until they forgive. In this line Haddad uses 'ilmu al-ma'ani, in the aspectof kalam al-khabar, whose purpose is to express the weakness (izhar ad-da'fi). Thus, before they forgive the mistakes of Qays and Layla, Qays and Layla will always be sad.

Stanza 3 consists of 13 lines (26-38). Line 26 begins with a sentence repeatingthe $1^{\text {st }}$ line of stanza 1 and the $12^{\text {th }}$ line of stanza 2, indicating that this line is the beginning of the new stanza. It means the same expression: I will talk about Layla. What is meant by the pronoun $/ 2 a /(I)$ in $/$ sa aqulu $/(I$ will talk) is Qays.

Next, we proceed to line 27. Qays will tell about the ever-crying traveler. The term /al-musafir/ in this line is Qays. ThusQays will tell about himself who always cries all the way in his journey. In this line, Haddad uses the rhetorical aspect of 'ilmu al-ma'ani,kalam al-khabar, with the aim of tahassur (expressing sorrow).

Next, we proceed with line 28. In this line Qays will tell about the enchanting charm seen from the words in her eyes. In this line, Qays will tell about how Layla is so enchanting to him. It is seen from his words. In this line, Haddad uses the language styleilmu al-bayan, in the aspect ofisti'aratmakniyat, to personify the eyes acting like humans who can utter words.

What follows after is line 29, whereQays wants to tell about a meaningless pleasure because I spend it to wander. What is meant by the subject pronoun / $u$ / in / uqdi/ (I spend) is Qays. In this line, Haddad uses 'ilmu al-ma'ani, in the aspect of kalam al-khabar whose purpose is to express tahassur(sadness).

In line 30, Qays will tell about the mirror that radiates to meet the lust of the youth. The pronoun /ha/ (she) in /marayahal (mirror) refers to Layla. Meanwhile, what is meant by the word /maraya/ (mirror) is the light. In Arabicrhetoric, such case can be included in the 'ilmu al-bayan, in themajazmursalaspectspecifically using sabbabiyatalaqat, when one meansthe light by mentioning a mirror, because it is a mirror that reflects the light.

After that, in line 31, Qays will tell about her exciting specialities. The pronoun of /-ha/ (her) in /mayyazaniha/(her specialities) also refers to Layla. So, the point is that Layla has exciting distinguishing features. In this line Haddad uses 'ilmual-ma'ani, in the aspect of 'ijaz, where he uses one word or phrase in a statement in which there are various elements. In this line, the only word mentioned is/mayyazan/(specialities), whereas what is meant by the word is trulyher beauty, her eloquent utterance, her attitude and other features that seems distinguished and special, according to Qays.

Next, in line 32, Qays will tell about herunfair justice. This line also still talks about Layla. Then, what is the meaning ofher unjust justice? Is Layla unjust? Yes, because Layla only gives her love to Qays, not to others. Literally, it appears that Qays only conveys the ordinary information that Layla is unfair, but looking at the implied meaning, it turns out that this statement contains the meaning of pride (al-fakhr) which belongs to the aspect of kalam al-khabar, in 'ilmual-ma'ani. The statement about the unfairness of is intended for the public, because Layla grantsher love only to Qays. But for Qays personally, this is something that is fair.

The $32^{\text {nd }}$ line is followed by the $33^{\text {rd }}$ line, whereQays will tell about my journey that is full of chatter. The pronoun /i/ (my)in /safari/ (my journey) refers to Qays. Therefore, in this line, Qays will talk about himself. Haddad uses the rhetorical aspect of 'ilmu al-ma'ani, kalam al-khabar, whose purpose is fai'dat al-khabar, which is to only provide information.

In line 34, Qays will tell about a woman mad in love who chooses to die. What is meant by the word /jinniyat/ (a woman mad in love) here is Layla. So, Qays wants to talk about Layla who is crazy about him, and willingly dies for him. In this line, through the mouth of Qays, Haddad usesthe rhetorical aspect of 'ilmual-ma'ani, kalam 
al-khabar, with the aim of al-fakhr (pride), that Qays prided himself for there is a woman who goes mad and willingly dies for him.

In this line, Layla is referred to as a mad woman. Is this the truth?

This is followed by line 35, which means for me, even though her position is above me. This line is a continuation from the previous line, but a line break of enjambment is added at the word /laylaya/ (for me). If this line is combined with the previous line, the meaning turns to beabout a woman mad in love who chooses to die for me. The expression is thenfollowedbythe clause even though her position is above me. The pronoun /ha/ (her) in the word /yaduha/ (her position) refers to none other than Layla. In contrast to the previous line, in this line Haddad usesthe rhetorical aspect of 'ilmual-ma'ani, kalam al-khabar, with the aim of 'izhar ad-da'fi (showing weakness), asQays says that he is inferior to Layla. Textually, the word /yadun/generally means hand, but contextually the word /yadun/ can be translatedto position. This kind of rhetoric belongs to ilmu al-bayan, in the majazmursalaspect, where the relation between the figurative and the literal meaning is sabatiyat, meaning the hand is the one that causes the presence of power andauthority.

This line is then followed by line 36, and although my position is destined to be the messenger.It begins with the $/ w a /$ (and) particle, which indicates that this line is a continuation from the previous line. The word pronoun /i/ (-my) in /yaddi/ (my position) refers toQays. Thus, Qays is positioned as more inferior than Layla. The rhetoric used in this line is 'ilmu al-ma'ani, in the aspect of kalam al-khabar whose purpose is to show weakness ('izhar ad-da'fi), thatQays considers himself to be a messenger.

Next, we proceed to line 37, which means I will tell about her who iscalledmad when I'm mad. The pronoun of the subject $/ \mathrm{a} /$ in the word $/ \mathrm{sa}$ `aqulu/refers to Qays and the pronoun / $\mathrm{ha} / \mathrm{her}$ ) in the word /'anha/ (about her) refers to Layla. This line and the next line are the last lines of this poem. In this line, Qays will tell us that at the end of this story, he and Layla are both mad, because of love. This corresponds to the end of the story in the moreoriginal prose.

Next, in line 38, the last line and as the ending of this poem, Qays conveys that and I apologise if I reachmy death shortly after this. This line begins with the /wa/particle, indicating that this line is still a continuation of the previous line. Like the original story, which ends with the death of Qays, Haddad also concludes this poem with contents relating to the death of Qays.

Thus Haddad describes Layla through Qays's point of view. The results of analysing one stanza to another, and one line to another, this poem is not much different from the poem /'an Qays/. Therefore, if it is compared with the prose versions, the text that depicts the character Layla is almost identical to the text found in Qays, since these poems only describe characters, withouttouching other aspects, such as the background story and others. Likewise the way Haddad uses his rhetoric, it is almost the same as the previous poem. There are many phrases depicting the character Layla which are not as varied and precise as those used by the authors who wrote the prose stories. This may be the quirks of Haddad's poetry. He wanted to take advantage of his freedom as a poet in describing the characters.

\section{CONCLUSION}

After the study these poems is conducted byanalysingin the typography aspect, it is found that the relationship between the form and the contents is quite related. Haddad divided thepoems into three stanzas, each consisting of different numbers of lines. Stanza 1 consists of 10 lines, stanza 2 consists of 7 lines and stanza 3 consists of 20 lines. Moreover, each stanza is marked with the same word, /sa'aqulu 'an Qays/. This shows that Haddad wanted to divide this poem into three parts, namely the beginning, middle and end. This chapter division seems to follow the original storyline of LaylaMajnun. The number of lines at the beginning of the story is more than the middle part, because there is a lot of the story to deliver, which is the love story of Qays and Layladuringchildhood and adolescence. Then, the story continues in the middle part of which the number of lines is less, because there is less of the story to be conveyed, which is about the rejection of Qays by Layla's father, thus causing them to separate from each other. Finally, at the end of poem the lines are the most in number, because there is a lot of the story to be conveyed, which is the story of Qayssetting out a journey in search for Layla only to become majnun (mad) until the end of his life.

Looking at its typographic form, Haddad deliberately align all the lines in the centre to show that the love story between Qays and Layla is uncertain. This is in line with the originalLaylaMajnun story. This idea is supported by the various forms of the lines, there are short ones and there are long ones, there are lines truncated by enjambments and there are complete ones, revealing many twists and turns of the love story.

On a different note, judging by its contents, there is not much picture of LaylaMajnun's love story revealed in the poem due toits form written as a monologue rather than a narrative.There are manyexpressions that are less understandable,due to the fact thatthey arerichinfigurative and connotative words inconsistent with the original story. Moreover, all the stanzas in the poem begins with the words /sa `aqulu `an Qays/ (I will talk about Qays), whereas in it nothing is truly told. Nevertheless, it is the right of the author to make such depictions, although this makes the poem unable to describe the story of LaylaMajnun in its truest form. 
This article recommends the story to be inspired well in poetry, it is expected to be written in the form of a diaphanous and easily digestible poem, rather than prismatic, diatribeable, or it should be written in the form of a free and prosaic poem, with simple typography and does not necessarily use of too many enjambements.

\section{BIBLIOGRAPHIES}

[1]. Aminuddin (1987), PengantarApresiasi Karya Sastra. Bandung: C.V. Sinar Baru

[2]. Atmazaki (1990). Ilmu Sastra Teori dan Terapan. Padang: Angkasa Raya.

[3]. Campo, Juan Eduardo, (2009) Encyclopedia of Islam, USA: Facts on File Inc

[4]. Ganjavi, Nizami, (2012), Pengantin Surga, Jakarta: Dolphin.

[5]. Haddad, Qasim, (2014), Chronicles of Majnun Layla and Selected Poems, Translated by Ferial Ghazaouldan John Verlenden, New York: Cyracuse University Press

[6]. Al-Jarim, Ali and Musthafa Amin. (2013), Balāghatul Wādhihah. Bandung: Sinar Baru Algensindo

[7]. Lesmana, Maman (2010). Cinta dalam Dua Puisi Toeti Heraty. Depok: Fakultas Ilmu Pengetahuan Budaya, Universitas Indonesia

[8]. Lewis, Bernard, (2001), Music of a Distant Drum: Classical Arabic, Persian, Turkish, and Hebrew Poems, New Jersey: Princenton University Press

[9]. Luxemburg, Jan Van, (1989), Pengantar Ilmu Sastra. Jakarta: PT Gramedia.

[10]. Schielke, Joska Samuli (2015), Egypt in The Future Tense, USA: Indiana University Press

[11]. Tirtawirya, PutuArya (1983). Apresiasi Puisi dan Prosa. Flores: Nusa Indah 